\title{
Developing a Model of 'Proficiency in English' for the Indonesian Local Context: Some Considerations from the English as an International Language (EIL) Perspective
}

\author{
${ }^{1}$ S Imelwaty, ${ }^{2}$ T Helda, ${ }^{3}$ E Kemal, ${ }^{4} \mathrm{~L}$ Perpisa \\ $\left\{{ }^{1}\right.$ imelwaty05@ @stkip-pgri-sumbar.ac.id, ${ }^{2}$ trisna_helda@yahoo.co.id, ${ }^{3}$ edwarkemal@gmail.com, \\ ${ }^{4}$ liliperpisa@gmail.com \} \\ ${ }^{1,2,3,4}$ STKIP PGRI Sumatera Barat Padang, Indonesia
}

\begin{abstract}
Based on the 'anti-normative paradigms', English is viewed as a pluricentric language that there is no uniform standard norm for it. This sociolinguistics reality has become an issue for English language educators particularly in the context where English has not been used for daily local communications. Confusions arise among them as which models of English should be taught to their English language learners. To this end, the study was conducted to develop a model of 'Proficiency in English' which may suit with the local English language learners and users in the Indonesian local context. An iterative design-based research approach was employed consisting of four main stages. This article only reports the results of the second stage of the study that offers a solution by reconstructing the model of 'Proficiency in English' for the Indonesian local context within English as an International Language (EIL) perspective which embraces all kind of varieties of English equally.
\end{abstract}

Keywords: 'Proficiency in English', English language teaching (ELT), English as an International Language (EIL)

\section{INTRODUCTION}

The privilege of varieties of English from the inner circle countries [1] particularly the varieties of American and British English has been dominated in the English language teaching (henceforth ELT) for many years. The aim of ELT has always focused on achieving the standard forms of English which are not attainable for the non- L1 English speakers whose first language is not English. In the context in which English does not have a function as an official language, the goal of learning English is to have native-like proficiency which is measured in reference to the famous 'Standard' Englishes such as American and British English [2].

For many years, the construct of language proficiency has been debated concerning the attributes in it. In a broad sense, Renandya [3] describe that 'language proficiency refers to one's ability to use language for a variety of communicative purposes'. The meaning of language proficiency particularly in English has become complicated since English is not only used by the monolingual native speaker but also in multilingual contexts. Furthermore, English has been acknowledged to have a special status in many countries around the world as an official language [4]. For this reason, the English speakers become bilingual and multilingual with their multicultural backgrounds. It is more than 80 percent of communication is happening among non-native speakers of English around the world [5].

There is evidence regarding the number of non-native speakers of English that outnumber the native speaker ones and the various varieties of English existing in the world 
communication. English should not be seen as a single variety but it has been transformed into various ones. According to [6] this sociolinguistic realities have inspired a number of linguists and applied linguists to develop the frameworks or academic approaches i.e. English as an International Language (EIL), World Englishes (WE), English as a Lingua Franca (ELF) to conceptualizing, researching, and learning/teaching English. These frameworks have categorized as the 'anti-normative paradigm' [7] which embrace and acknowledge the varieties of English.

In the context of ELT in Indonesia, the American and British English are still regarded as a point of reference. To this end, the 'Western paradigm of English language teaching' [8] has dominated the practices of the teachers of English in Indonesia. In term of proficiency, the English language learners are expected to have the native speaker-like proficiency which they are never able to attain. Their English proficiency is still being measured against the native speaker of English norms based on the assumption that the English users in Indonesia would use English to communicate with the native speaker of English [9], [10]. Such a condition needs to be changed because the English learners and users in Indonesia do not only need to communicate with native speakers of English but also to the non-native ones. Thus, an appropriate model of 'Proficiency in English' which could inform English language pedagogy in the Indonesian context needs to be developed.

The aim of this study is to develop a model of 'Proficiency in English' that meets with the Indonesian local context. The ultimate goal of learning English for Indonesian now is to be able to communicate cross-culturally either with native or non-native speakers of English. This model is being developed inductively to gain the basic needs of the Indonesian for using English. English as an International language (henceforth EIL) is employed as its perspective 'embraces/recognizes all varieties of English at national, regional, social, and idiolectal levels in all circles as equal' [6]. Within this perspective, the native English speaker-like proficiency is challenged as it does not promote English as a pluricentric language [11].

\section{RESEARCH METHOD}

This study employed a design-based research approach for designing the model of 'Proficiency in English'. This design is adopted because the model which is being developed should be suitable for the local context. Wang [12] describe that design-based research (henceforth DBR) is an 'a systematic, but flexible methodology aimed to improve educational practices through iterative analysis, design, development, and implementation, based on collaboration among researchers and practitioners in real-world settings, and leading to contextually-sensitive design principles and theories'. In other words, this design is also applicable for improving educational practices such as English language teaching as it employs a collaboration of team researchers and language educators in the real world setting. The participants of this study are the practitioners comprising a cohort of teachers of English around West Sumatra province in Indonesia and English language educators at a tertiary level.

In addition, DBR comprises cyclical and iterative process [12] that the model of 'Proficiency in English could be refined to meet with the Indonesian local needs. To this end, the development of design principles will undergo a series of testing and refinement cycles. Data is collected systematically in order to re-define the problems, possible solutions, and the principles that might best address them. As data is re-examined and reflected upon, new designs are created and implemented, producing a continuous cycle of design-reflection-design. In other words, the problem, solutions, methods, and the designed principles are continuously refined, tested and developed as the knowledge enhanced [13]. 
There are four main stages in the process of this study as seen in Figure 1. They are (1) the analysis of practical problems, (2) the development of solutions, (3) the evaluation research of the solutions in practice, and (4) the reflection to produce design principles and enhance solution implementation [13]. Within these stages, it is seen that the nature of DBR is dynamic and flexible research process.

This article is only focusing on reporting the results of the second stage of the study that offers a solution by reconstructing the model of 'Proficiency in English' for the Indonesian local context. The results of the first stage of the study show the practical problems faced by the teachers of English in ELT i.e. the dilemma of employing their endonormative model of English to their students in the process of teaching English and their desired goal for attaining the exonormative model of English. The results of the first stage could inform the second stage of the study which is focusing on the development of the solutions of the problems faced by the local English language educators and the learners as well. The model of 'Proficiency in English' was then being designed using the existing principles and the innovations in ELT. This process involves imagining a solution and analyzing whether it will work or not. In addition, the model is tested against the researchers' knowledge and theory, the identified problems, and the improved solutions before committing to implement it.

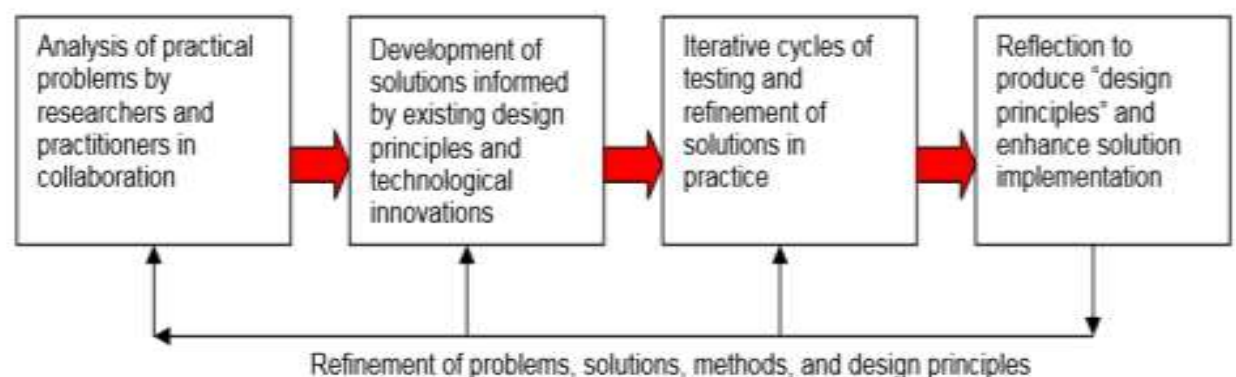

Figure 1. Design-based research, based on Amiel and Reeves (2008)

\section{RESULTS AND DISCUSSION}

In the first stage of the study, there is evidence that the teachers of English have been teaching English using the local variety of English. Their English could not be regarded as the English of native speakers such as American or British English. Despite exposing the language learners with their local variety or the endonormative model of English, the norms of the socalled native speakers or the exonormative model of English were still being taught and used as references. However, from exploring the teachers' personal constructs, it was also found that the needs to use English for cross-cultural communication, expressing their local identities along with the needs to adhere to the exonormative model of English, particularly in the academic context.

The results of the first stage of the study were used to inform the development of the model of 'Proficiency in English' which could be the frame of reference for being proficient in English in the Indonesian context. In addition, the existing principles from previous studies and also the innovations within ELT were adopted to reconstruct the model of 'Proficiency in English' for 
the Indonesian local context. To this end, the EIL perspective was adopted as the nature of the model acknowledging the pluralistic forms of English. In the context of this study, a perspective means 'a paradigm for thinking, research, and practice' [14]. There are several considerations to adopt this EIL perspective as they are explained in the following points:

1. English is not used for everyday communication among Indonesian. Most of Indonesian speak more than one language, their mother tongue, and Bahasa Indonesia. To acquire English proficiency is limited to certain communities as elitist accomplishment [7]. This means that only the Indonesian, who has a privilege to pursue education to a higher level, certainly has access to learn and to use English. In the educational context, English is needed for pursuing opportunities to gain higher education and as a result, the English of the educated Indonesians could be used as a model.

2. The practice of ELT has been traditionally oriented to the norms of English which are based on the inner circle countries (e.g. Britain and America). This kind of practice needs to be challenged as English is not a single variety as Sharifian [14] argues that 'English, with its many varieties, is a language of international and intercultural communication'. It is necessary for Indonesian to communicate interculturally and internationally in order to be able to compete in a global world without losing their local identity.

3. A growing number of studies which promote EIL such as a study by Briguglio [15] that English language users need to expect and be able to deal with different varieties of English; show acceptance toward different accents in English; and develop communication strategies to deal with different accents and way of speaking in English (where differences are perhaps more marked than in writing). In addition, many prolific scholars in the field (to name a few Alsagoff [16]; Matsuda [17]; McKay [18]; Smith [19]; Sharifian [14]) have been rigorously promoting the significance of teaching English as a heterogeneous language with multiple grammars, vocabulary, accents, and pragmatic discourse conventions [2].

Referring to those considerations, this study has made an attempt to offer a solution by reconstructing the model of 'Proficiency in English' for the Indonesian context within EIL perspective which embraces all kind of varieties of English equally. The model of 'Proficiency in English' for this study was also informed by the three dimensional (3D) framework of language variation which was developed by Mahboob [2] (also see [20]). This framework also identifies four continua: users, uses, mode, and time that help us understand how language varies based on who is using it, for what purposes, with what resources, and when [2]. In other words, it becomes the basic framework of language variation in a particular context.

Based on the Indonesian local context needs, the model of 'Proficiency in English' was developed by accommodating various English norms ranging from the exonormative model of English ['Standard' British or American English] which is appropriately used by the distant social relation users informal communications as for academic purposes, to the exonormative model of English [in this context, the local variety of English] which is used by the close social relation users in non-formal communications as for communicative purposes. There is a continuum to help the English language learners and its users in determining the position of their English variations without being judged for using 'deviant' English. This model also provides a conceptual framework for language educators and English language learners in Indonesia to shift the goal of learning and using English for not only aware and experience the 
exonormative model of English but also the exonormative model of English based on with who using it, what purpose for using it and when to use it in accordance to the contexts [21].

\section{CONCLUSIONS}

The sociolinguistic realities which are encountered by English language educators, learners, and users in Indonesia have created problems in defining the attributes of being proficient in English. Being proficient in English does not only mean having the knowledge and abilities in the exonormative model of English but also the endonormative one. Therefore, for the local contexts, the model of 'Proficiency in English' has to accommodate not only the exonormative model of English but also the endonormative one. As in the first stage of the study, the practical problems had been identified so that in this second stage, the development of the model could be conducted. Referring to some considerations from the EIL perspective, the existing model of language proficiency by Mahboob [2] has inspired and informed the researchers to design the model of 'Proficiency in English' that meets with the local context. It is hoped that this model could help English language educators, learners and users to make decisions and to consider the choices of who use, what purpose, and when to use both either exonormative or endonormative model of English.

\section{ACKNOWLEDGMENTS}

This research project was funded by in the Ministry of Research, Technology and Higher Education of the Republic of Indonesia in 2018 and 2019. We also thank the local high school English teachers in West Sumatra province, Indonesia, who have participated in the research process and provided insights that greatly assisted this research.

\section{REFERENCES}

[1] B. B. Kachru, The alchemy of English. Oxford: Pergamon Press, 1986.

[2] A. Mahboob, "Understanding language variation: Implications of the NNEST lens for TESOL teacher education programs," in Native and Non-Native Speakers in English Language Teaching: Implications and challenges, J. de D. M. Agudo, Ed. Boston: De Gruyter Mouton, 2017.

[3] W. A. Renandya, F. A. Hamied, and J. Nurkamto, "English Language Proficiency in Indonesia : Issues and Prospects," J. Asia TEFL, vol. 15, no. 3, pp. 618-629, 2018.

[4] D. Crystal, English as a Global language. Cambridge, 2003.

[5] D. Graddol, English Next. London: British Council, 2006.

[6] R. Marlina, "The Pedagogy of English as an International Language ( EIL ): More Reflections," in The Pedagogy of English as an International Language: Perspectives from Scholars, Teachers, and Students, Springer, 2014, pp. 1-20.

[7] R. Kubota, "The politics of EIL: Toward border-crossing communication in and beyond English," in Principles and practices of teaching English as an international language, A. Matsuda, Ed. Bristol: Multilingual Matters, 2012, pp. 55-69.

[8] H. Wang and C. Hill, "A Paradigm Shift for English Language Teaching in Asia," Imposition, vol. 8, no. 4, pp. 205-232, 2011.

[9] J. . Brown, "Comment 1: What do we mean by bias, Englishes, Englishes in testing, and English language proficiency?," World Englishes, vol. 23, no. 2, pp. 317-319, 2004.

[10] J. Jenkins, "The spread of EIL: A testing time for testers," ELT J., vol. 60, no. 1, pp. 
42-50, 2006.

[11] M. Clyne, Ed., Pluricentric Languages: Differing Norms in Different Nations. Berlin et.al: Mouton de Gruyter., 1992.

[12] F. Wang and M. J. Hannafin, "Design-based research and technology-enhanced learning environments," Educ. Technol. Res. Dev., vol. 53, no. 4, pp. 5-23, 2005.

[13] T. Amiel and T. C. Reeves, "Design-based research and educational technology: Rethinking technology and the research agenda," Educ. Technol. Soc., vol. 11, no. 4, pp. 29-40, 2008.

[14] F. Sharifian, English as an international language: Perspectives and pedagogical issues. Bristol: Multilingual Matters, 2009.

[15] C. Briguglio, "The use of English as a global language in multinational settings and the implications for business education," The University of Western Australia, Western Australia, 2005.

[16] L. Alsagoff, S. McKay, G. Hu, and W. Renandya, Principles and Practices for Teaching English as an International Language. New York: Routledge, 2012.

[17] A. Matsuda, Principles and practices of teaching English as an international language. Bristol: Multilingual Matters, 2012.

[18] S. L. McKay, Teaching English as an international language. Oxford: Oxford University Press, 2002.

[19] L. E. Smith, Readings in English as an international language. Oxford: Pergamon Press, 1983.

[20] A. Mahboob, Dynamic Approach to Language Proficiency. 2015.

[21] K. Saddhono, "Language of Coastal Communities in the Northern Coast of Central Java: Sociolinguistic Studies in Cultural Integration Maritime-Agrarian Perspective." Adv. Sci. Let. vol. 23 no. 10 pp 10054-10056, 2017 